\title{
Radiation Sensitivity of Cajanus Cajan to Gamma Radiations
}

\section{Darakhshanda Neelam ${ }^{1}$, Tanveera Tabasum¹, Husain SA ${ }^{1}$, Mahmooduzaffar $^{2}$ and Shahnaz Subhan ${ }^{3}$}

${ }^{1}$ Department of Biosciences, Jamia Millia Islamia, Jamia Nagar, New Delhi, 110025, India

${ }^{2}$ Department of Botany, Jamia Hamdard, New Delhi, 110062, India

${ }^{3}$ Amity Institute of Biotechnology, Amity University, Noida, U.P -201301, India

\begin{abstract}
Gamma irradiation induces various physiological, biochemical alterations in plants with modulation of certain metabolic and defensive pathway. Pre-sowing seed irradiation is considered as an effective method of improving production, yield components and chemical composition in plants. In the present study Cajanus Cajan was subjected to gamma irradiation with absorbed doses 0 Gy, $30 \mathrm{~Gy}, 50 \mathrm{~Gy}, 100 \mathrm{~Gy}, 150 \mathrm{~Gy}$ and $200 \mathrm{~Gy}$ with a dose rate 2.08 Kilo Gray per hour $\left(2.08 \mathrm{KGh}^{-1}\right)$. Cajanus cajan when exposed to variable doses of gamma radiation showed persistent changes in the growth and development under both in vivo \& in vitro conditions. Radiation sensitivity test based on germination percentage of irradiated and non-irradiated seeds demonstrated that significant reduction in germination percentage was observed with increasing gamma dosage under both in vivo and in vitro conditions. Biochemical analysis confirmed that protein, photosynthetic pigments, proline are very sensitive to gamma radiation, and are good indicators of tolerance. Effective stimulatory dose for plant development under in vivo conditions is 100 Gy while the absorbed doses of $150 \mathrm{~Gy}$ and $200 \mathrm{~Gy}$ can prove detrimental. However under in vitro conditions, results hold $150 \mathrm{~Gy}$ as threshold dose for increasing plant growth, plant vigour and development. Conclusively productivity of Cajanus cajan and consequent economic gains could be enhanced through adoption of suitable cultivar and level of gamma radiation. Gamma rays prove to be an important tool in increasing the breeding efficiency and regeneration frequency, especially that of the recalcitrant varieties. Results in the present study provide sufficient evidence to the effect that $\mathrm{\gamma}$-irradiation does activate a biochemical system.
\end{abstract}

Keywords: Gamma rays; Radiation sensitivity; Proline; Total soluble protein; Cajanus cajan

\section{Introduction}

Unlike conventional breeding procedures which involve the production of new genetic combinations from already existing parental genes, nuclear technology causes exclusively new gene combinations with high mutation frequency. Mutation induction with radiation is most frequently used method to develop direct mutant varieties, as improvement with limited genetic variation. The first attempts to stimulate plant growth by exposing seeds or growing plants to optimum doses of ionizing radiation or by the use of radioactive fertilizers, dates back to the 1960s [1]. The use of the ionizing radiation technology may be considered as a revolution in agronomic research, especially in the plant protection, plant breeding and crop production [2,3]. Gamma rays fall into the category of ionizing radiation and interact with atoms or molecules to produce free radicals in cells [4]

Gamma irradiation induces various physiological and biochemical alterations in plants. Gamma irradiation leads to changes in the plant cellular structure and metabolism [5,6]. Gamma-irradiation can be useful for the alteration of one or a few physiological characters [7]. Several positive mutations have been created in agricultural crops by using gamma irradiations Crops with improved characteristics have successfully been developed by mutagenic inductions [8-10] like high yielding barley variety with early maturity, high protein contents and stiff straw by mutation breeding techniques. Khatri et al. [11] collected three high grain yielding and early maturing mutants by treating seeds of Brassica juncea L. cv. S-9 with gamma rays (750-1000 KGy). Shah et al., developed a new oil seed Brassica napus L cv. ABASIN-95 by induced mutation. The many mutant varieties, which are resistant to diseases, cold, salt and with high quality have also been developed [12].

Pre-sowing seed irradiation is also an effective method of improving production, yield components and chemical composition in plants [13-19] concluded that physical methods for processing of pre-sowing seed stimulates physiological and biochemical changes in the seeds. Studies by Deaf and Zheljazkov et al. [20-24] have also been carried out to elucidate the effects of gamma rays on some aromatic plants and legumes.

The aim of the present investigation was to assess the use of gamma radiation as a physical elicitor to alter the physiological characteristics of Cajanus cajan after exposures of pre-sowing seeds to variable doses of gamma rays under in vivo and in vitro conditions.

\section{Materials and Methods}

Cajanus cajan L. was selected for the present study. The healthy and authentic seeds were obtained from Division of Genetics (Pulse research) Indian Agricultural Research Institute, New Delhi. Cajanus cajan L. is a perennial member of the family Fabaceae. It ranks sixth in the area of production in comparison of other grain legumes $\&$ is one of the most valuable legumes grown in semi-arid and sub-tropical areas of the world. It is used in more diverse ways than others \& exhibits notable pharmacological effects.

For in vivo and in vitro studies, seeds were irradiated with gamma radiation of absorbed doses $0 \mathrm{~Gy}, 30 \mathrm{~Gy}, 50 \mathrm{~Gy}, 100 \mathrm{~Gy}, 150 \mathrm{~Gy}$ and 200 Gy. The device used was Gamma Cell GC-5000 BRIT-BOMBAY. The source of gamma radiation was Cobalt-60; with a dose rate 2.08 Kilo Gray per hour $\left(2.08 \mathrm{KGh}^{-1}\right)$ at Indian Institute of Nuclear Medicine and Allied Sciences (INMAS) New Delhi. Seed germination rate under both

*Corresonding author: Darakhshanda Neelam, Department of Biosciences, Jamia Millia Islamia, Jamia Nagar, New Delhi, 110025, India, E-mail: darakshanda_s@ yahoo.co.in

Received September 18, 2014; Accepted October 29, 2014; Published November 06, 2014

Citation: Neelam D, Tabasum T, Husain SA, Mahmooduzaffar, Subhan S (2014) Radiation Sensitivity of Cajanus Cajan to Gamma Radiations. J Food Process Technol 5: 394. doi:10.4172/2157-7110.1000394

Copyright: @ 2014 Neelam D, et al. This is an open-access article distributed unde the terms of the Creative Commons Attribution License, which permits unrestricted use, distribution, and reproduction in any medium, provided the original author and source are credited. 
in vivo and in vitro conditions was carried out by radiation sensitivity test to determine the germination percentage after exposure to the gamma radiation. Germination percentage (GP) was calculated by using the following formula:

$$
G P=\frac{\text { Number of seeds germinated }}{\text { Total number of seeds sowed }} \times 100
$$

Fully opened leaves of individual plants were counted. The area of leaves was measured by using a leaf area meter (model 3000A, LICOR, USA) in centimeters $(\mathrm{cm})$. Numbers of branches were counted at different stages of plant growth. The root and shoot length were measured in centimeters. For biomass of the root, leaves, and stem the samples were oven dried separately at $80^{\circ} \mathrm{C}$ for $48 \mathrm{hrs}$ and dry weight was determined on a digital balance. Percent dry wt. of samples was calculated by using following formula:

$$
\% d r y \text { weight }=\frac{\text { Dry weight }}{\text { Fresh weight }} \times 100
$$

For biochemical analysis, chlorophylls and caroteniods were measured from the fresh leaf by the method of Hiscox and Israeltam [25]. The total soluble protein content of different sample explants was estimated following the method of Bradford [26]. The soluble protein concentrations were quantified with the help of standard curve prepared from the standard of bovine albumin serum (BSA) from sigma, USA. The protein content was expressed in $\mathrm{mg} \mathrm{g}^{-1}$ fr.wt. The proline content was estimated by the method of Bates et al. [27]. The corresponding concentration of proline was determined against the standard curve processed in the same manner using L-proline (sigma). The amount of proline was expressed as $\mu \mathrm{g} \mathrm{g}^{-1}$ fr.wt.

\section{Results}

The results for radiation sensitivity test based on germination percentage carried out under in vivo \& in vitro conditions demonstrated significant reduction in germination percentage with increasing absorbed doses of gamma radiation. On an average, the mean germination percentage was greater for control, $30 \mathrm{~Gy}, 50 \mathrm{~Gy}$ and $100 \mathrm{~Gy}$ and lowest for $150 \mathrm{~Gy}$ and $200 \mathrm{~Gy}$ (Figure 1). For the germination percentage of irradiated seeds to reach $50 \%$, the gamma dosage administered was $200 \mathrm{~Gy}$. Under in vivo studies among the vegetative traits, root shoot ratio, shoot dry weight, total number of branches per plant showed a significant $(\mathrm{p}<0.05)$ increase with plant age in control as well as in treated plants (Tables 1-3). With increasing absorbed doses of gamma radiation, the vegetative traits showed linear increase up to 100Gy and thereafter showed a significant decrease with increase in absorbed doses.

A significant variation in growth was observed micro-shoots attained from gamma irradiated cultures were compared with respect to control (without irradiation) (Table 4). Under in vitro studies, the growth response of directly regenerated plantlets showed a significant $(\mathrm{p}<0.05)$ increase with plant age in controls as well as in treated plants (Figure 2). Increase in number of shoots up to 4 weeks showed a direct co-relation with increasing absorbed doses of gamma radiation as compared to control. However, after 4-weeks due to necrosis, plantlets at absorbed dose 200 Gy were not able to withstand irradiation effects, leading to decrease in the number of shoots. Maximum numbers of shoots were noted at the absorbed dose of $150 \mathrm{~Gy}$, which produced about 9shoots /explant at 12 weeks of culture while minimum number of shoots was noted at 30 Gy (Figure 4). In case of leaf number, maximum number of leaves / explant were noted at absorbed dose 150
Gy with 10 leaves /plant while minimum number of 5 leaves /plant at 30 Gy were observed (Table 1).

Number of seeds per plant and weight of 100 seeds showed significant $(\mathrm{p}<0.05)$ increase upto the absorbed dose of $100 \mathrm{~Gy}$ (Figure 3). Absorbed doses ( $30 \mathrm{~Gy}, 50 \mathrm{~Gy} \& 100 \mathrm{~Gy}$ ) reflected a stimulatory effect of gamma irradiation on number of seeds as compared to non-irradiated (control) (Figure 5). The maximum enhancement was observed with 50 Gy \& 100 Gy. However, a significant decrease in number of seeds was observed with increasing doses of gamma radiation. Maximum decline was observed with 150 Gy \& 200 Gy. Maximum variation of $39.09 \%$ was observed with 100 Gy followed by $23.05 \%$ at $50 \mathrm{~Gy}$. Weight of 100 seeds exhibited the similar trend with maximum variation of $97.05 \%$ with $100 \mathrm{~Gy}$ and minimum variation of $22.06 \%$ with 200 Gy (Table 5).

Chlorophyll ' $a$ ' content enhanced significantly $(\mathrm{p}<0.05)$ with increasing doses of gamma radiation under both in vitro and in vivo conditions up to flowering stage and thereafter declined steadily (Figure 6). However Chlorophyll ' $b$ " content declined significantly $(\mathrm{p}<0.05)$ with increasing doses of gamma radiation under both in vitro and in vivo conditions (Figure 6). A dosage dependent significant $(\mathrm{p}<0.05)$ increase in total chlorophyll content was also found under in vitro and in vivo conditions. A dosage dependent significant $(\mathrm{p}<0.05)$ increase in caroteniod content was also found under in vitro and in vivo conditions. A dosage dependent significant $(\mathrm{p}<0.05)$ increase in soluble protein content was found under in vitro and in vivo conditions (Figure 7). Proline content in both in vivo \& in vitro conditions showed a significant $(\mathrm{p}<0.05)$ increase with increasing doses of gamma radiation (Figure 8).

\section{Discussion}

Radiation sensitivity test is a prerequisite step before the mutagenic treatment is started. The main purpose of this test is to investigate the most effective dosage of irradiation to be used and also to estimate the frequency and mutation spectrum using gamma irradiation. The results in the present study for radiation sensitivity test based on germination

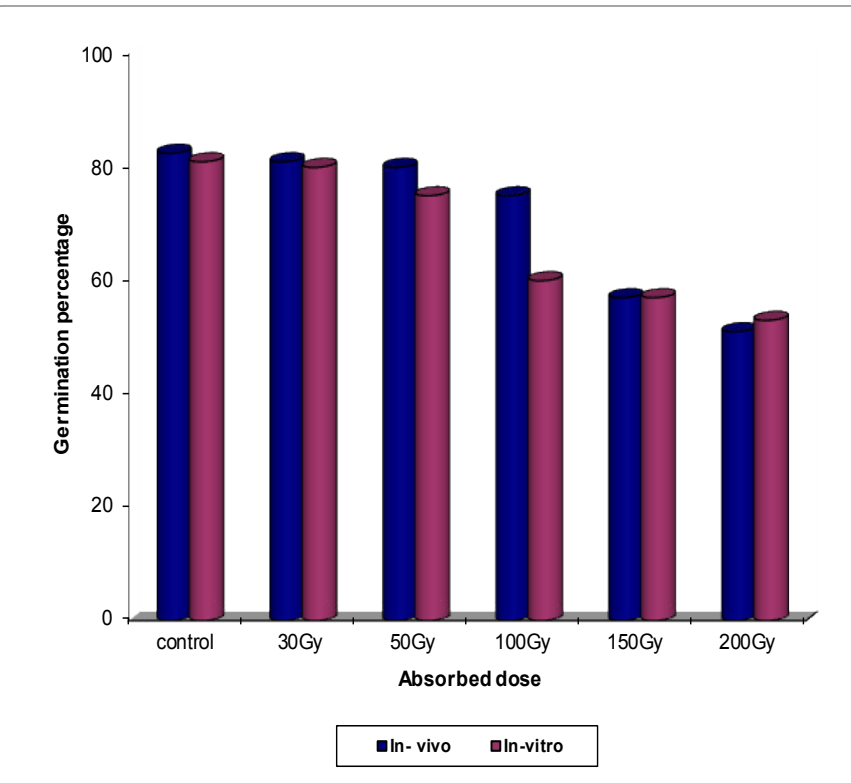

Figure 1: Radiation sensitivity test to determine the germination percentage after exposure to the gamma irradiation 


\begin{tabular}{|c|c|c|c|}
\hline \multirow[t]{2}{*}{ Treatments } & \multicolumn{3}{|c|}{ Developmental stages } \\
\hline & Pre- Flowering & Flowering & Post- Flowering \\
\hline Control & $\begin{array}{l}0.24 \pm 0.01 \\
(0.00)\end{array}$ & $\begin{array}{l}0.28 \pm 0.01 \\
(0.00)\end{array}$ & $\begin{array}{l}0.33 \pm 0.01 \\
(0.00)\end{array}$ \\
\hline $30 \mathrm{~Gy}$ & $\begin{array}{l}0.25 \pm 0.01 \\
(4.16)\end{array}$ & $\begin{array}{l}0.31 \pm 0.01 \\
(10.71)\end{array}$ & $\begin{array}{l}0.35 \pm 0.01 \\
(4.94)\end{array}$ \\
\hline $50 \mathrm{~Gy}$ & $\begin{array}{l}0.27 \pm 0.01 \\
(12.50)\end{array}$ & $\begin{array}{l}0.34 \pm 0.01 \\
(21.43)\end{array}$ & $\begin{array}{l}0.37 \pm 0.01 \\
(8.82)\end{array}$ \\
\hline $100 \mathrm{~Gy}$ & $\begin{array}{l}0.27 \pm 0.01 \\
(12.50)\end{array}$ & $\begin{array}{l}0.35 \pm 0.01 \\
(22.03)\end{array}$ & $\begin{array}{l}0.38 \pm 0.01 \\
(9.00)\end{array}$ \\
\hline $150 \mathrm{~Gy}$ & $\begin{array}{l}0.24 \pm 0.01 \\
(0.00)\end{array}$ & $\begin{array}{l}0.28 \pm 0.01 \\
(0.00)\end{array}$ & $\begin{array}{l}0.31 \pm 0.01 \\
(8.82)\end{array}$ \\
\hline $200 \mathrm{~Gy}$ & $\begin{array}{l}0.23 \pm 0.01 \\
(4.17)\end{array}$ & $\begin{array}{l}0.27 \pm 0.01 \\
(3.57)\end{array}$ & $\begin{array}{l}0.29 \pm 0.01 \\
(14.71)\end{array}$ \\
\hline
\end{tabular}

${ }^{*} \mathrm{P} \leq 0.05$

CD at $5 \%$

Developmental Stages: $0.010^{*}$

The values represent Mean \pm SE $(n=3)$

Treatments: $0.070^{*}$

Parenthesis shows percent variation.

Table 1: Variation in Root: Shoot ratio in cajanus cajan $\mathrm{L}$. at various growth stages treated with different doses of Gamma radiations under in vivo conditions

\begin{tabular}{|l|l|l|l|}
\hline Treatments & \multicolumn{2}{|l|}{ Developmental stages } & \\
\hline & Pre- Flowering & Flowering & Post- Flowering \\
\hline \multirow{2}{*}{ Control } & $\begin{array}{l}4.10 \pm 0.11 \\
(0.00)\end{array}$ & $\begin{array}{l}4.62 \pm 0.12 \\
(0.00)\end{array}$ & $\begin{array}{l}4.90 \pm 0.13 \\
(0.00)\end{array}$ \\
\hline \multirow{2}{*}{$\mathbf{5 0}$ Gy } & $\begin{array}{l}5.04 \pm 0.13 \\
(22.93)\end{array}$ & $\begin{array}{l}5.34 \pm 0.14 \\
(15.58)\end{array}$ & $\begin{array}{l}5.74 \pm 0.13 \\
(17.14)\end{array}$ \\
\hline \multirow{2}{*}{$\mathbf{5 0}$ Gy } & $\begin{array}{l}5.74 \pm 0.15 \\
(40.00)\end{array}$ & $\begin{array}{l}5.98 \pm 0.16 \\
(29.44)\end{array}$ & $\begin{array}{l}6.10 \pm 0.16 \\
(24.49)\end{array}$ \\
\hline \multirow{2}{*}{$\mathbf{1 0 0}$ Gy } & $5.86 \pm 0.10$ & $6.10 \pm 0.11$ & $6.38 \pm 0.11$ \\
\hline \multirow{2}{*}{$\mathbf{1 5 0}$ Gy } & $(40.35)$ & $(31.26)$ & $(29.61)$ \\
\hline \multirow{2}{*}{$\mathbf{2 0 0}$ Gy } & $3.39 \pm 0.09$ & $3.95 \pm 0.10$ & $4.14 \pm 0.11$ \\
& $(17.32)$ & $(14.50)$ & $(15.51)$ \\
\hline
\end{tabular}

${ }^{*} \mathrm{P} \leq 0.05$

$\mathrm{CD}$ at $5 \%$

Developmental Stages: $0.154^{*}$

The values represent Mean \pm SE $(n=3)$

Treatments: $0.119^{*}$

Parenthesis shows percent variation.

Table 2: Variation in shoot dry Weight (gms) in Cajanus cajan L. at various growth stages treated with different doses of Gamma radiation under in vivo conditions

\begin{tabular}{|l|l|l|l|}
\hline Treatments & \multicolumn{2}{|l|}{ Developmental stages } & \\
\hline & Pre- Flowering & Flowering & Post- Flowering \\
\hline Control & $\begin{array}{l}6.00 \pm 0.16 \\
(0.00)\end{array}$ & $\begin{array}{l}8.50 \pm 0.23 \\
(0.00)\end{array}$ & $\begin{array}{l}9.00 \pm 0.24 \\
(0.00)\end{array}$ \\
\hline \multirow{2}{*}{ 0 Gy } & $\begin{array}{l}7.50 \pm 0.13 \\
(25.00)\end{array}$ & $\begin{array}{l}10.00 \pm 0.27 \\
(17.65)\end{array}$ & $\begin{array}{l}11.50 \pm 0.20 \\
(27.78)\end{array}$ \\
\hline \multirow{2}{*}{$\mathbf{5 0}$ Gy } & $\begin{array}{l}9.00 \pm 0.24 \\
(50.00)\end{array}$ & $\begin{array}{l}12.50 \pm 0.22 \\
(47.06)\end{array}$ & $\begin{array}{l}15.50 \pm 0.42 \\
(72.22)\end{array}$ \\
\hline \multirow{2}{*}{$\mathbf{1 0 0}$ Gy } & $9.50 \pm 0.29$ & $\begin{array}{l}12.50 \pm 0.18 \\
(47.53)\end{array}$ & $\begin{array}{l}16.00 \pm 0.14 \\
(73.11)\end{array}$ \\
\hline \multirow{2}{*}{$\mathbf{5 0}$ Gy } & $(50.67)$ & $\begin{array}{l}5.00 \pm 0.14 \\
(41.18)\end{array}$ & $\begin{array}{l}6.50 \pm 0.11 \\
(27.78)\end{array}$ \\
\hline \multirow{2}{*}{$\mathbf{2 0 0}$ Gy } & $(25.00)$ & $\begin{array}{l}5.00 \pm 0.13 \\
(41.18)\end{array}$ & $\begin{array}{l}6.01 \pm 0.10 \\
(33.32)\end{array}$ \\
\hline
\end{tabular}

${ }^{*} \mathrm{P} \leq 0.05$

The values represent Mean \pm SE $(n=3)$

$\mathrm{CD}$ at $5 \%$

Treatments: $0.195^{*}$

Developmental Stages: 0.252*

Treatment $\times$ Developmental stages: $0.436^{*}$

Parenthesis shows percent variation.

Table 3: Variation in total number of branches per plant in Cajanus cajan L. at various growth stages treated with different doses of Gamma radiation under in vivo conditions percentage of irradiated and non-irradiated seeds demonstrated that significant reduction in germination percentage was observed with increasing gamma dosage under both in vivo and in vitro conditions. These results are in accordance with the radiation sensitivity test done by Norfadzrin et al. [28] whereby increasing gamma dosages also decrease the germination percentage of tomato and okra. The inhibition of seed germination at higher doses of radiation may have resulted from damage to chromosomes and subsequent mitotic retardation Al-Safadi and Simon et al. [29-33].

A decreasing trend in plant biomass with increasing gamma dose exposure suggests that there was radiation effect on carbon gain. Reduced carbon gain following higher gamma dosage has also been supported by various authors [34-36]. Decrease in the number of branches and leaf following higher gamma dosage from flowering to post-flowering stages is distinct. This might be due to premature abscission, induced as a result of increased production of ethylene [3739]. Similar variability in seeds /pods has been recorded by Sharma et al. [40-42]. The increased average leaf area per plant would be expected to enhance the rate and efficiency of photo synthesis, which leads to a marked rise in plant biomass and consequently, would be associated with improved productivity. Authors Dubey et al. [41-45] have reported increment in seed yield following gamma radiations. At higher doses, number of seeds per plant decreased significantly. In the previous research, similar findings have also been reported by Sharma et al. in green gram, Charumathi, et al. in black gram and Gupta and Sharma in horse gram.

Chlorophyll content in the present study, showed a dosage dependent significant increase under in vitro and in vivo conditions which are in accordance with the results of Alikamanoglu et al. [46,47]. In addition, it was also observed that the concentration of chlorophyll $a$ was relatively higher than chlorophyll $b$ in irradiated and nonirradiated plants Modulation in photosynthesis in irradiated plants might partly contribute to increased growth Wi et al. $[48,49]$. Gamma irradiation resulted in greater reduction in the amount of chlorophyll $\mathrm{b}$ as opposed to chlorophyll a Fukuzawa et al. [50-52]. The reduction in chlorophyll $b$ is due to a more selective destruction of chlorophyll $b$ biosynthesis or degradation of chlorophyll $b$ precursors Mishra et al.

Following higher doses of gamma radiation, there was increase in total caroteniod content in both in vivo \& in vitro conditions. Caroteniods function both as photosynthetic pigments and endogenous antioxidants, absorbing surplus energy and quenching active oxygen in addition to protecting chlorophyll by absorption of photon energy Casarett et al. [53-56].

In this study, it was found that there was an irregular distribution of total soluble protein content in irradiated plantlets under both in vivo and in vitro conditions. According to the results obtained in the present study, under in vivo conditions, it was observed that absorbed doses (150 Gy \& $200 \mathrm{~Gy}$ ) displayed lower total soluble protein content. However, under in- vitro conditions soluble protein content showed a linear increase with increasing doses of gamma radiation. These results are in accordance with Cho and Song who observed that gamma irradiation did not induce significant loss in water soluble components such as total soluble proteins. Some investigators have observed slight depression or increase, while others reported no significant changes. During gamma irradiation of tomatoes, protein synthesis was not stopped but restored to form different set of proteins called as gamma induced proteins. The function of these is not yet known, but they may be involved in physiological disorders triggered by irradiation in repair process. 
Citation: Neelam D, Tabasum T, Husain SA, Mahmooduzaffar, Subhan S (2014) Radiation Sensitivity of Cajanus Cajan to Gamma Radiations. J Food Process Technol 5: 394. doi:10.4172/2157-7110.1000394

Page 4 of 7

\begin{tabular}{|c|c|c|c|c|}
\hline & Treatments & 4- weeks & 8- weeks & 12 - weeks \\
\hline \multirow{6}{*}{ 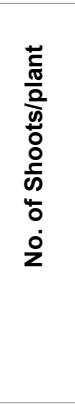 } & Control & $\begin{array}{c}4.66 \pm 2.08 \\
(0.00)\end{array}$ & $\begin{array}{c}4.96 \pm 0.57 \\
(0.00)\end{array}$ & $\begin{array}{c}5.33 \pm 2.08 \\
0.00\end{array}$ \\
\hline & $30 \mathrm{~Gy}$ & $\begin{array}{c}3.63 \pm 1.15 \\
(22.10)\end{array}$ & $\begin{array}{c}4.33 \pm 0.57 \\
(12.70)\end{array}$ & $\begin{array}{c}5.0 \pm 1.00 \\
(6.19)\end{array}$ \\
\hline & $50 \mathrm{~Gy}$ & $\begin{array}{c}4.43 \pm 3.05 \\
(4.94)\end{array}$ & $\begin{array}{c}5.09 \pm 1.52 \\
(2.62)\end{array}$ & $\begin{array}{c}6.66 \pm 2.51 \\
(81.24)\end{array}$ \\
\hline & $100 \mathrm{~Gy}$ & $\begin{array}{c}4.66 \pm 2.08 \\
(0.00)\end{array}$ & $\begin{array}{c}6.31 \pm 2.10 \\
(27.22)\end{array}$ & $\begin{array}{c}6.90 \pm 2.03 \\
(32.69)\end{array}$ \\
\hline & $150 \mathrm{~Gy}$ & $\begin{array}{c}6.00 \pm 1.00 \\
(28.76)\end{array}$ & $\begin{array}{c}7.33 \pm 2.00 \\
(62.90)\end{array}$ & $\begin{array}{c}8.08 \pm 1.15 \\
(37.52)\end{array}$ \\
\hline & $200 \mathrm{~Gy}$ & $\begin{array}{c}7.33 \pm 1.52 \\
(57.30)\end{array}$ & $\begin{array}{c}5.98 \pm 1.52 \\
(2.42)\end{array}$ & $\begin{array}{c}5.50 \pm 2.03 \\
(10.69)\end{array}$ \\
\hline \multirow{5}{*}{ 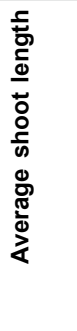 } & Control & $\begin{array}{c}5.66 \pm 0.71 \\
(0.00)\end{array}$ & $\begin{array}{c}7.40 \pm 0.96 \\
(0.00)\end{array}$ & $\begin{array}{c}7.83 \pm 0.76 \\
(0.00)\end{array}$ \\
\hline & $30 \mathrm{~Gy}$ & $\begin{array}{c}5.50 \pm 1.50 \\
(41.25)\end{array}$ & $\begin{array}{c}5.76 \pm 1.49 \\
(49.36)\end{array}$ & $\begin{array}{c}6.00 \pm 0.50 \\
(53.83)\end{array}$ \\
\hline & $50 \mathrm{~Gy}$ & $\begin{array}{c}5.83 \pm 1.04 \\
(23.89)\end{array}$ & $\begin{array}{c}6.08 \pm 0.78 \\
(45.96)\end{array}$ & $\begin{array}{c}7.66 \pm 0.73 \\
(20.04)\end{array}$ \\
\hline & $100 \mathrm{~Gy}$ & $\begin{array}{c}6.06 \pm 0.76 \\
(13.05)\end{array}$ & $\begin{array}{c}7.36 \pm 0.72 \\
(21.70)\end{array}$ & $\begin{array}{c}8.33 \pm 1.04 \\
(23.08)\end{array}$ \\
\hline & $150 \mathrm{~Gy}$ & $\begin{array}{c}6.66 \pm 0.78 \\
(20.89)\end{array}$ & $\begin{array}{c}8.16 \pm 2.75 \\
(13.19)\end{array}$ & $\begin{array}{c}9.09 \pm 1.09 \\
(53.00)\end{array}$ \\
\hline है & $200 \mathrm{~Gy}$ & $\begin{array}{c}3.16 \pm 0.76 \\
(58.75)\end{array}$ & $\begin{array}{c}4.46 \pm 1.38 \\
(52.55)\end{array}$ & $\begin{array}{c}4.50 \pm 0.50 \\
(58.45)\end{array}$ \\
\hline \multirow{6}{*}{ 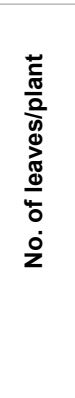 } & Control & $\begin{array}{c}5.31 \pm 1.54 \\
(0.00)\end{array}$ & $\begin{array}{c}6.24 \pm 2.51 \\
(0.00)\end{array}$ & $\begin{array}{c}7.21 \pm 1.52 \\
(0.00)\end{array}$ \\
\hline & $30 \mathrm{~Gy}$ & $\begin{array}{c}5.12 \pm 0.89 \\
(40.42)\end{array}$ & $\begin{array}{c}5.33 \pm 3.05 \\
(14.30)\end{array}$ & $\begin{array}{c}6.32 \pm 1.40 \\
\quad(5.29)\end{array}$ \\
\hline & $50 \mathrm{~Gy}$ & $\begin{array}{c}6.33 \pm 1.40 \\
(23.83)\end{array}$ & $\begin{array}{c}7.52 \pm 2.05 \\
(33.38)\end{array}$ & $\begin{array}{c}8.00 \pm 2.00 \\
\quad(7.41)\end{array}$ \\
\hline & $100 \mathrm{~Gy}$ & $\begin{array}{c}7.66 \pm 1.58 \\
(7.82)\end{array}$ & $\begin{array}{c}7.66 \pm 1.55 \\
(42.15)\end{array}$ & $\begin{array}{c}8.88 \pm 0.52 \\
(34.66)\end{array}$ \\
\hline & $150 \mathrm{~Gy}$ & $\begin{array}{c}8.00 \pm 1.73 \\
(3.73)\end{array}$ & $\begin{array}{c}8.53 \pm 1.05 \\
(46.90)\end{array}$ & $\begin{array}{c}9.01 \pm 1.52 \\
\quad(40.41)\end{array}$ \\
\hline & $200 \mathrm{~Gy}$ & $\begin{array}{c}6.93 \pm 1.40 \\
(16.61)\end{array}$ & $\begin{array}{c}7.01 \pm 0.01 \\
(62.16)\end{array}$ & $\begin{array}{c}7.05 \pm 1.03 \\
(53.37)\end{array}$ \\
\hline
\end{tabular}

${ }^{*} \mathrm{P} \leq 0.05$

CD at $5 \%$

Developmental Stages: $0.133^{*}$

Parenthesis shows percent variations
The values represent Mean \pm SE $(n=3)$

Treatments: $0.103^{*}$

Treatment $\times$ Developmental stages: $0.230^{*}$

Table 4: Variation in number of in vitro raised microshoots (MS $-2 \mathrm{mg} / \mathrm{BAP}$ ) at different doses of gamma radiation
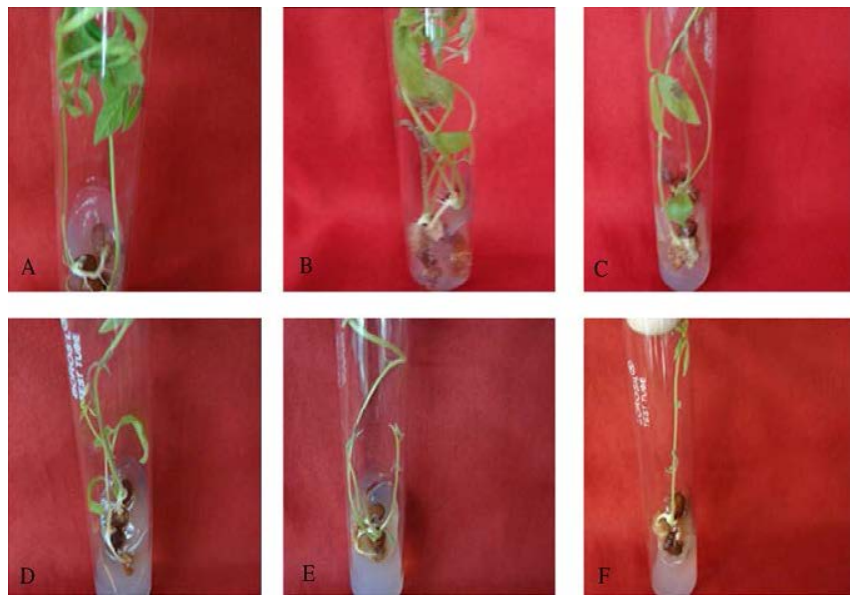

Figure 2: Variation in plant growth under invitro conditions after treatment with different doses of gamma radiation. A: control; B: $30 \mathrm{~Gy}$;C: $50 \mathrm{~Gy}$; D: $100 \mathrm{~Gy}$; E: 150Gy; F: 200Gy.

In the present study, proline content in both in vivo \& in-vitro conditions showed an significant increase with increasing doses of gamma radiation which are in accordance with the findings of Esfandiari et al. [57]. Gamma irradiation leads to modulation of certain metabolic and defensive pathways. One of the protective mechanisms is the synthesis of osmolytes which is essential to plant growth in proline synthesis .Gamma irradiation at certain doses promotes the level of antioxidants. Gamma radiation at higher doses induce oxidative stress with overproduction of reactive oxygen species (ROS) such as superoxide radicals, hydroxyl radicals and hydrogen peroxide, which react rapidly with almost all structural and functional organic molecules, including proteins, lipids and nucleic acids causing disturbance of cellular metabolism [58-60].

\section{Conclusion}

Conclusively productivity of Cajanus cajan and consequent economic gains could be enhanced through adoption of suitable cultivar and level of gamma radiation. Results in the present study provide sufficient evidence to the effect that $\gamma$-irradiation does activate a biochemical system. Biochemical analysis confirmed that the differences between various cultures in their ability to accumulate such compounds were evident under stress but not under controlled conditions. Yield parameters showed a significant enhancement with 
Citation: Neelam D, Tabasum T, Husain SA, Mahmooduzaffar, Subhan S (2014) Radiation Sensitivity of Cajanus Cajan to Gamma Radiations. J Food Process Technol 5: 394. doi:10.4172/2157-7110.1000394
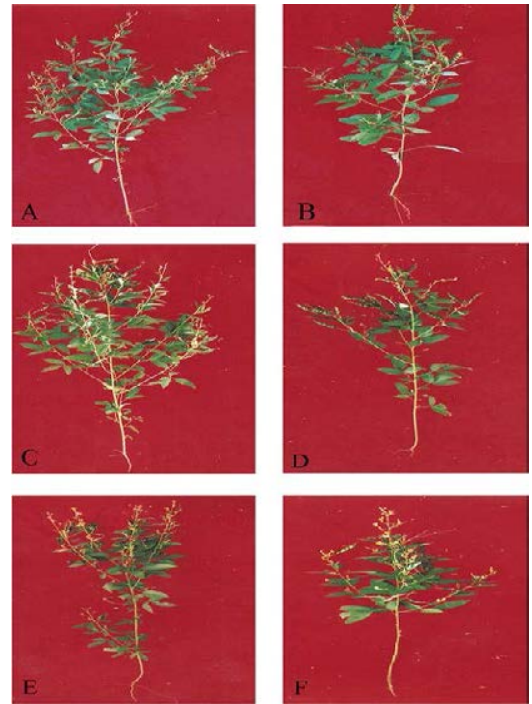

Figure 3: Variation in of formation of pods under in vivo conditions after treatment with different doses of gamma radiation. A: control; B: 30Gy; C: 50Gy; D: 100Gy; E: 150Gy; F: 200Gy
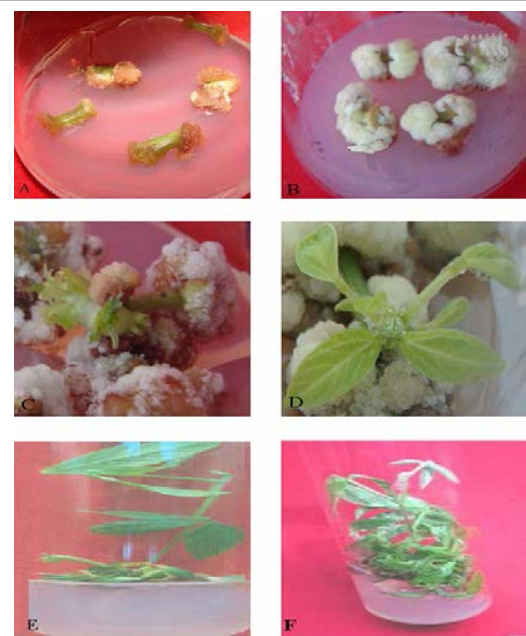

Figure 4: Increase in callus formation / regenaeration frequency after irradiation with different doses of gamma radiation.

A: Callus growth in controlled cultures; B: Callus growth in irradiated cultures $\mathrm{C}$ : Induction of shoots in controlled cultures.;D: Induction of shoots in irradiated cultures; E: Induction of multiple shoots in controlled cultures; F: Induction of multiple shoots in irradiated cultures.

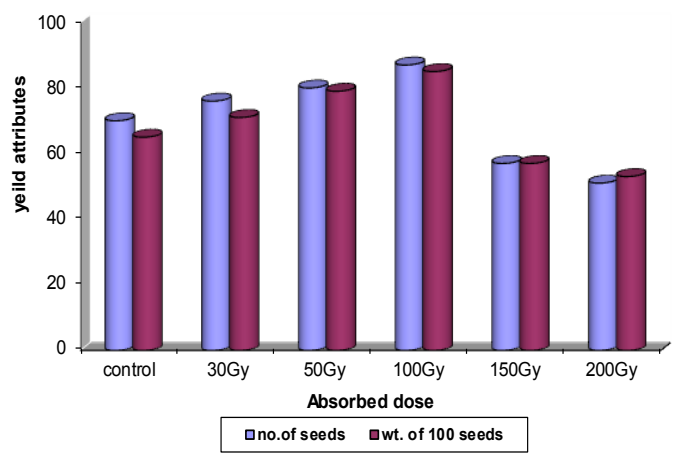

Figure 5: Variation in in -vivo yield attributes in Cajanu cajan at different doses of gamma radiation

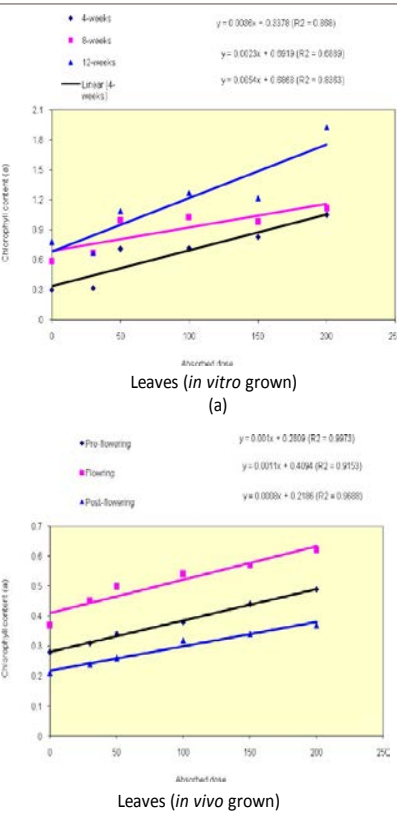

(c)

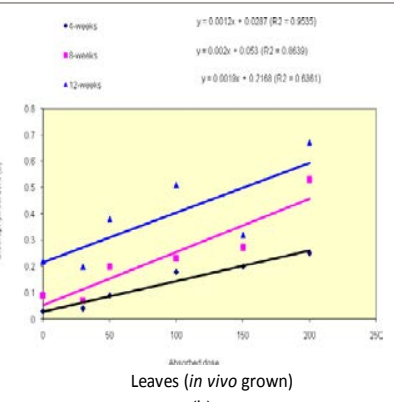

(b)

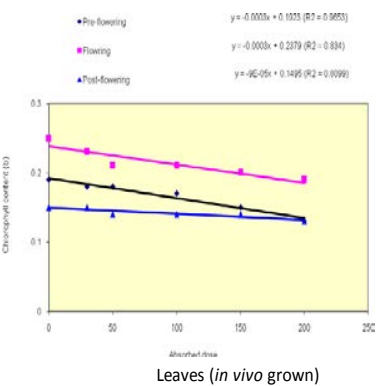

Figure 6: Variation in chlorophyll 'a' and 'b' in C. cajan L. at various growth stage under in vivo \& in vitro conditions treated with different doses of Gamma radiation

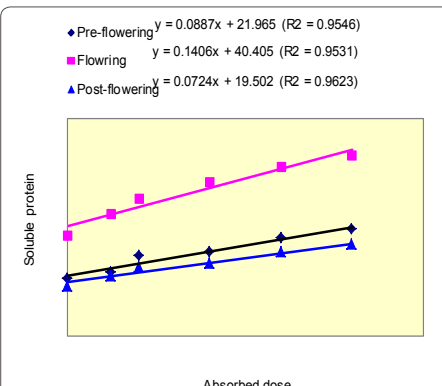

Leaves (in vivo grown)

-4-weeks $y=0.0171 x+0.8321(R 2=0.9347)$

-8-weeks $y=0.0264 x+1.3106(R 2=0.9412)$

$\Delta$ 12-weeks $y=0.0257 x+4.955(R 2=0.9114)$

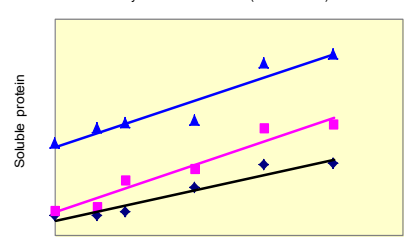

-4-weeks $y=0.0107 x+1.7154(R 2=0.9301)$ =8-weeks $y=0.0218 x+4.9287(R 2=0.9763)$ 12-weeks $y=0.0225 x+5.772(R 2=0.9376)$

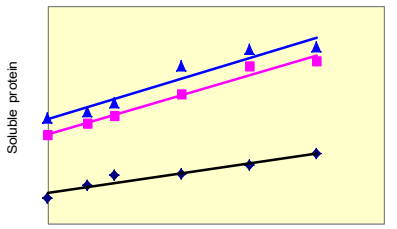

Absorbed dose (b)

4-weeks $y=0.0044 x+7.8987\left(R_{2}=0.1484\right)$

$y=0.131 x+4.4214(122=0775)$

12-weeks $y=0.0025 x+6.6781(R 2=0.162)$

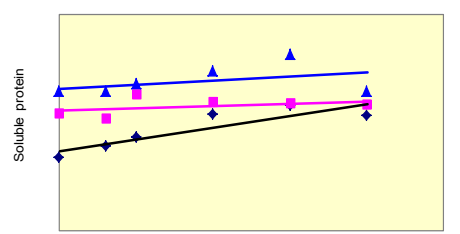

Figure 7: Variation in soluble protein in C.cajan $L$. at various growth stages under in vivo \& in vitro condition treated with different doses of Gamma radiation

absorbed dose of $100 \mathrm{~Gy}$. Optimum doses of ionizing radiations have modulatory role in the growth and developmental processes. Effective stimulatory dose for plant development under in vivo conditions is $100 \mathrm{~Gy}$ while the absorbed doses of $150 \mathrm{~Gy}$ and $200 \mathrm{~Gy}$ can prove detrimental. However under in vitro conditions, results hold 150 Gy as threshold dose for increasing plant growth, plant vigour and development. Gamma rays prove to be an important tool in increasing the breeding efficiency, and regeneration frequency, especially that of the recalcitrant varieties. In this context, further work is required where the response of plant to different doses of gamma radiation can 
Citation: Neelam D, Tabasum T, Husain SA, Mahmooduzaffar, Subhan S (2014) Radiation Sensitivity of Cajanus Cajan to Gamma Radiations. J Food Process Technol 5: 394. doi:10.4172/2157-7110.1000394

Page 6 of 7

\begin{tabular}{|c|c|c|c|c|c|c|}
\hline \multirow{2}{*}{ Treatments } & \multicolumn{3}{|l|}{ Dry. Wt. (gm) † Shoot } & \multicolumn{3}{|l|}{ Dry. Wt. (gm) † Root } \\
\hline & 4- weeks old & 8-weeks old & 12 weeks old & 4- weeks old & 8-weeks old & 12 weeks old \\
\hline Control & $1.12 \pm 0.03(0.00)$ & $2.03 \pm 0.04(0.00)$ & $3.11 \pm 0.06(0.00)$ & $0.03 \pm 0.02(0.00)$ & $0.03 \pm 0.01(0.00)$ & $0.04 \pm 0.02(0.00)$ \\
\hline 30Gy & $1.26 \pm 0.03(12.50)$ & $2.36 \pm 0.05(16.25)$ & $3.44 \pm 0.05(10.61)$ & $0.03 \pm 0.02(0.00)$ & $0.03 \pm 0.02(0.00)$ & $0.03 \pm 0.02(25.00)$ \\
\hline 50Gy & $1.45 \pm 0.06(29.46)$ & $2.50 \pm 0.06(23.15)$ & $3.75 \pm 0.09(20.57)$ & $0.04 \pm 0.02(33.33)$ & $0.02 \pm 0.01(-33.33)$ & $0.02 \pm 0.01(40.0)$ \\
\hline $100 G y$ & $1.63 \pm 0.05(45.53)$ & $3.12 \pm 0.09(53.20)$ & $4.44 \pm 0.08(42.76)$ & $0.03 \pm 0.01(0.00)$ & $0.05 \pm 0.01(66.67)$ & $0.06 \pm 0.01(50.0)$ \\
\hline 150Gy & $1.74 \pm 0.08(55.36)$ & $3.28 \pm 0.12(61.15)$ & $4.94 \pm 0.10(64.30)$ & $0.02 \pm 0.01(33.33)$ & $0.04 \pm 0.01$ & $0.04 \pm 0.02(0.00)$ \\
\hline 200Gy & $1.24 \pm 0.03(12.50)$ & $2.13 \pm 0.04(15.89)$ & $3.05 \pm 0.06(6.05)$ & $0.02 \pm 0.01(33.33)$ & $0.03 \pm 0.01(88.0)$ & $0.03 \pm 0.02(65.0)$ \\
\hline
\end{tabular}

${ }^{*} \mathrm{P} \leq 0.05$

The values represent Mean $\pm \mathrm{SE}(\mathrm{n}=3)$

CD at $5 \% \quad$ Treatments: $0.026^{*}$

Developmental Stages: $0.033^{*} \quad$ Treatment $\times$ Developmental stages: $0.058^{*}$

Parenthesis shows percent variations

Table 5. Variation in dry weight of Shoot and Root grown under in vitro conditions at different doses of gamma radiation. (Mean \pm SD in gm.)

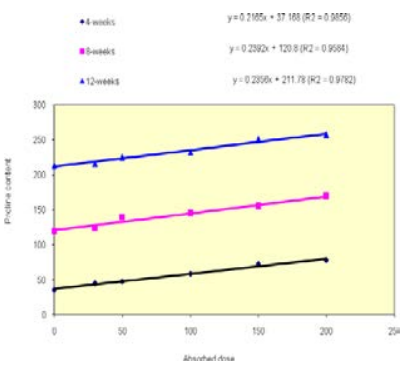

Non- regenerative calli (in vitro grown) (a)

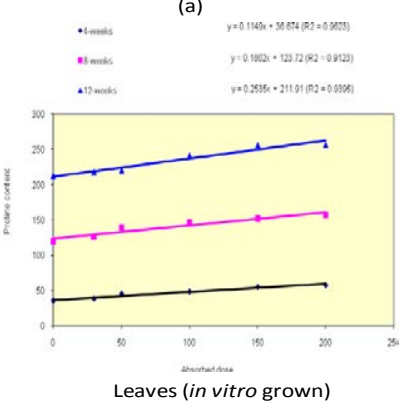

(c)

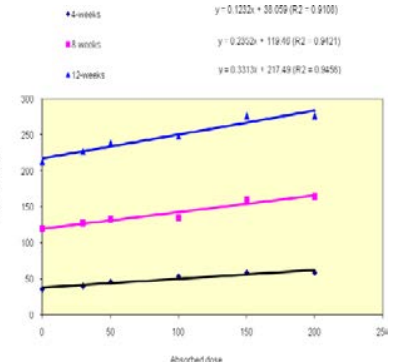

(b)

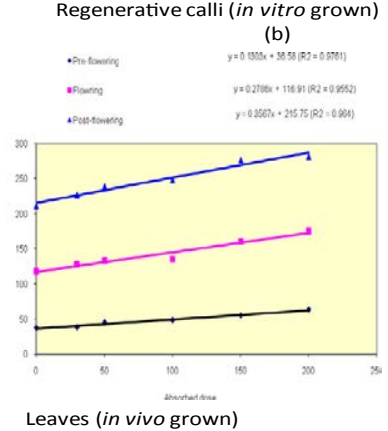

(d)

Figure 8: Variation in proline content in C. cajan L. at various growth stage treated with different doses of Gamma radiation

be elaborated.

\section{Acknowledgements}

I acknowledge with gratitude the help rendered by faculty of Science, Jamia Hamdard, for providing me the necessary lab facilities to effectively carry out this work. My thanks are due to INMAS, New Delhi for providing me Gamma irradiation facility.

\section{References}

1. Sax K (1963) The stimulation of plant growth by ionizing radiation. Rad Botan 3: $179-186$.

2. El-Bazza Zainab EM, Halal AF, El-Fouli, Mohie EDZ, El-Tablawy Seham YM (2000) Inhibtory effect of gamma radiation and Nigella Sativa seeds oil on growth, spore germination and toxin production of fungi. Rad Phys Chem 60: 181-189.

3. Khan MM, Din R, Qasim R, Jehan S, Iqbal MM (2003) Induced Mutability studies for yield and yield related characters in three wheat (Triticum aestivum L.) varieties. As J Plant Sci 2: 1183-1187.

4. Kovács E, Keresztes A (2002) Effect of gamma and UV-B/C radiation on plant cells. Micron 33: 199-210.

5. Jain SM, Ahloowalia BS, Veilleux RE (1998) Somaclonal Variation and Induced Mutations in Crop Improvement. Plant Cell Tissue Organ Culture 7: 23-28.

6. Stoeva N (2002) Physiological effects of the synthetic growth regulator Thidiazurol (drop) on gamma-irradiated stress in peas plants (Pissum sativum). Journal of Central European Agriculture 6: 293-300.

7. Lapins T (1983) Mutation breeding: methods in fruit breeding. Gamma Field Symposia 3: 74-99.

8. Rehman A, Das ML, Howlidar MAR, Mansur MA (1987) Promising mutants in Brassica campestris. Mut Breed Newsletter 29: 14-15.

9. Javed MA, Khatri A, Khan IA, Ahmad M, Siddiqui MA, et al. (2000) Utilization of gamma irradiation for the genetics improvement of oriental mustard (Brassica juncea Coss.). Pak J Bot 32: 77-83.

10. Gustafsson A, Hagberg A, Persson G, Wiklund K (1971) Induced mutations and barley improvement. Theor Appl Genet 41: 239-248.

11. Khatri A, Khan I A, Siddiqui M A, Raza S, Nizamani GS ( 2005) Evaluation of high yielding mutants of Brassica Juncea cv. S-9 developed through Gamma rays and EMS. Pak J Bot 37: 279-284.

12. Wi SG, Chung BY, Kim JS, Kim JH, Baek MH, et al. (2006) Localization of hydrogen peroxide in pumpkin (Cucurbita ficifolia bouche) seedlings exposed to high- dose gamma ray. Journal of Plant Biology 49: 1-8.

13. Anisinov A, Vorobev V, Zuikov A (1997) The influence of laser radiation on the velocity of rotational motion of protoplasm in Elodea cells. Laser Physics 7: 1132-1137.

14. Galova Z (1996) The effect of laser beams on the process of germinating power of winter whear grains . Roczniki AR Pozananiu CCCLXXXVI 49: 39-43.

15. Grzesiuk S, Kulka K (1986) Physiology and biochemistry of seeds. PWRiL Warsaw

16. Khan BM (1970) Effect of gamma rays irradiation on yield and the incidence of blight disease of gram. Agriculture Journal of Pakistan 21: 43-61.

17. Podleomy J (2002) Studies on influence of laser light on seeds, growth, development and yielding of the white lupine (Lupinus albus L.) plants. Monografie Rozprawy Naukowe IUNG Puawy 3: 1-59.

18. Smith MT (1991) Ultrastructural changes during imbibition in seeds of lettuce (Latuca sativa L.) after gamma irradiation. Seed Science and Technology 19 : 385-395.

19. Selenia LV, Stepanenko OG (1979) Effect of preâ€"sowing gamma irradiation on the productivity and active principle content of Matricaria recutita. Rastitelnye Ressusy 15: 143-154.

20. Deaf NSD (2000) Chemical and biological studies on some wild plants. M.Sc Thesis, Fac. Agric, Zagazig Univ, Zagagzig Univ, Zagazig, Egypt.

21. Hepburn HA, Goodman BA, Mc Phail DB, Mathews S, Powell AA (1986) An evaluation of EPR measurements of organic free radical content individua seeds on then on destructive testing of seed viability. Journal of Expert Botany 37: $1675-1684$.

22. Mahmoud FAN (2002) Effect of gamma radiation and some agrochemicals on germination, growth and flowering of Delphinium ajacis and Mathiola incana plants. M.Sc Thesis Fac. Agric Moshtohor Zagazig Univ Egypt.

23. Youssef AA, Moussa AZ (1998) Effect of gamma rays on growth and essential oil composition of chamomile Chamomilla recutita L. Arab Universities Journal of Agricultural Sciences 6: 301 -311. 
Citation: Neelam D, Tabasum T, Husain SA, Mahmooduzaffar, Subhan S (2014) Radiation Sensitivity of Cajanus Cajan to Gamma Radiations. J Food Process Technol 5: 394. doi:10.4172/2157-7110.1000394

24. Zheljazkov V, Margine A, Stovea T, Shetty K (1996) Effect of gamma irradiation on some quantitative characteristics in mint and cornmint. Acta Horticulture 426: 381-388.

25. Hiscox JD, Isrealstam GF (1979) A method for extraction of chlorophyll from leaf tissue without maceration. Canadaian Journal of Botany 57: 1332-1334.

26. Bradford MM (1976) A rapid and sensitive method for the quantitation of microgram quantities of protein utilizing the principle of protein-dye binding. Analytical Biochemistry 72: 248-254

27. Bates LS, Waldren RP, Teare ID (1973) Rapid determination of free proline of water stress studies. Plant and Soil 39: 205-207.

28. Norfadzrin F, Ahmed OH, Shaharudin S, Rahman DA (2007) A Preliminary study on radiosensitivity of tomato (Lycopersicon esculentum) and okra (Abelmoschus esculentus). International Journal of Agricultural Research 2 620-625

29. Al-Safadi B, Simon PW (1996) Gamma irradiation induced variation in carrots (Daucus carota L.). Journal of American Society of Horticultural Sciences 121 599-603.

30. Chaudhuri KS (2002) A Simple and reliable method to detect gamma irradiated lentil (Lens culinaris Medik.) seeds by germination efficiency and seedling growth test. Radiation Physics Chemistry 64: 131-136.

31. Kiong ALP, Lai GA, Hussein S, Harun AR (2008) Physiological responses of Orthosiphon stamineus plantles to gamma irradiation. American Eurasian Journal Of Sustainable Agriculture 2: 135-149.

32. Kon E, Ahmed OH, Saamin S, Majid NM (2007) Gamma radiosensitivity study on Long bean (vigna sesquipedalis). American Journal of Applied Sciences 4 : 1090-1093.

33. Veeresh LC, Shivashankar G, Shailaga H, Hittalmani S (1995) Effect of seed irradiation on some plant characteristics of winged bean. Mysore Journal of Agricultural Sciences 29: 1-4

34. Kim JH, Chung B, Kim JS (2005) Effects of Planta gamma-irradiation on growth, photosynthesis, and Antioxidative capacity of Red pepper (Capsicum annuam L.) plants. Journal of Plant Biology 48: 47-56.

35. Thiede ME, Link SO, Fellows RJ, Beedlow PA (1995) Effects of gamma radiation on stem diameter growth, carbon gain and biomass partitioning in Helianthus annuus. Environmental and Experimental Botany 33-41.

36. Jia C, Li A (2008) Effect of gamma radiation on mutant induction of Fagopyrum dibotrys Hara. Photosynthetica 46:363-369.

37. Dwelle RB (1975) Abscission of Phaseolus and Impatiens Explants: Effects of lonizing Radiation upon Endogenous Growth Regulators and de Novo Enzyme Synthesis. Plant Physiol 56: 529-534.

38. Strydom GJ, Whithehead CS (1990) The effect on ionizing radiation on ethylene sensitivity and potharvest ripening of banana fruit. Scientia Horticulturae 41 : 293-304.

39. Buanong M, Kanlayanarat S (2010) Preservative solutions delay deterioration of inflorescences of Dendrobium sonia bom '17' following gamma irradiation. ISHS Acta. Horticulture 878: 417-422.

40. Sharma D, Sarma S, Talukdar (1991) Comparison of gamma ray and EMS induced variation in green gram (vigna radiate (L) Wilczek). Journal of Nuclear Agricultural Biology 20: 87-93.

41. Charumathi M, Rao MVB, Babu RV, Murthy KB (1992) Efficiency of early generation for induced micro mutations in black gram Vigna mungo L. Hepper. Journal of Nuclear Agriculture and Biology 21: 299-302.

42. Gupta VP, Sharma SK, Rathore PK (1996) Induced mutagenic response of gamma irradiation on horse gram (macrotyloma uniflorum). Indian Journal of Agricultural Science 66: 160-164.
43. Dubey AK, Yadav JR, Singh B (2007) Studies on induced mutuations by Gamma-irradiations in okra (Abelmoschus esculentus (L.) Moench. Programme. Agriculture 7: 46-48.

44. Mishra MN, Qadri H, Mishra S (2007) Macro and micro mutations, in gammarays induced $M_{2}$ populations of Okra (Abelmoschus esculentus $(L)$ Moench). Intern J Plant Sci 2: 44-47.

45. Sharma BK, Mishra MN (2007) Micro-mutations for fruit number, fruit length and fruit yield characters in gamma-irradiated generation of Ankur-40 variety of okra (abelmoschus esculnetus (L) Monech]. Int. Journal of Plant Sciences 2: 208-211.

46. Alikamanoglu S, Yaycli O, Atak C, Rzakoulieva A (2007) Effect of magnetic field and gamma radiation on Paulowinia Tomentosa tissue culture. Biotechnol. \& Biotechnol 21: 129-134.

47. Kim JH, Baek MH, Chung BY, Wi SG, Kim JS (2004) Alterations in the photosynthetic pigments and antioxidant machineries of red pepper (Capsicum annuum L.) seedlings from gamma-irradiated seeds. Journal of Plant Biology 47: 314-321.

48. Wi SG, Chung BY, Kim JH, Baek MH, Yang Lee JW, et al. (2005) Ultra structural changes of cell organelles in Arabidopsis Stem after $\hat{i}^{3}$-irradiation. Journal of Plant Biology 48: 195-200.

49. Strid A, Chow WS, Anderson JM (1990) Effects of supplementary gamma irradiation on photosynthesis in Pisum sativum. Biochemistry 1020: 260-268.

50. Fukuzawa K, Inokami Y, Tokumura A, Terao J, Suzuki A (1998) Single oxygen scavenging by alpha-tocopherol and beta-carotene: kinetic studies in phospholipid membranes and ethanol solution. Biofactors 7: 31-40.

51. Strid A, Porra RJ (1992) Alterations in pigment content in leaves of Pisum sativvum after exposure to supplementary UV-B. Plant \& Cell Physiology 33 1015-1023.

52. Wada H, Koshiba T, Matsui T, Sato M (1998) Involvement of peroxides in differential sensitivity to irradiation in seedlings of two Nicotiana species. Plant Sciences 132: 109-119.

53. Casarett AP (1968) Effects of radiation on higher plants and plant communities Ann NewYork Academic Sciences 59: 514-517.

54. Cho Y, Song KB (2000) Effect of gamma irradiation on the molecular properties of BSA and lactoglobulin. Journal of Molecular Biology 33: 133-137.

55. Lingakumar K, Kulandaivedu G (1993) Regulatory role of phytochrome on UV-B $(280-315 \mathrm{~nm})$ induced changes in growth and photosynthetic activities of Vigna sinensis. Phtosynthesis 29: 341-351.

56. Triantaphylides C, Banzet N, Ferullo JM, Larrigaudiere C, Nespoulous L (2004) Stress responses of tomato fruit tissue submitted to massive doses of ionizing radiation. Proc Royal Society of Ediburg Section B 102: 97-105

57. Esfandiari E, Shekari F, Shekari F, Esfandiari M (2007) The effect of salt stress on antioxidant enzymes activity and lipid peroxidation on the wheat seedling Not Bot Hort Agrobot. Cluj 35: 48- 56.

58. Al-Rumaih MM (2008) Influence of ionizing radiation on antioxidant enzymes in three species of Trigonella. American Journal of Environmental Sciences 4: 151-156.

59. Ashraf M (2009) Biotechnological approach of improving plant salt tolerance using antioxidants as markers. Biotechnol Adv 27: 84-93.

60. Grover HL, Nair TVR, Abrol YB (1978) Nitrogen metabolism of upper three leaf blades of wheat at different soil nitrogen levels. Physiologia Plantarum 42 287-292. 